\title{
H2BC5 wt Allele
}

National Cancer Institute

\section{Source}

National Cancer Institute. H2BC5 wt Allele. NCI Thesaurus. Code C116686.

Human H2BC5 wild-type allele is located in the vicinity of $6 \mathrm{p} 21.3$ and is approximately 13 $\mathrm{kb}$ in length. This allele, which encodes histone H2B type 1-D protein, is involved in nucleosome formation. 